August - 2004

\title{
Open University and Distance Education Coordination: Strategies used to consolidate distance education at the National Autonomous University of Mexico
}

\author{
Citlalli Berruecos \\ National Autonomous University of Mexico
}

\begin{abstract}
This case study describes three main strategies used from March 2002 to November 2003 at the Open University and Distance Education Coordination (CUAED) of the National Autonomous University of Mexico (UNAM) to consolidate distance education at the University. The author explains how, in just 18 months, these three main strategies enabled the UNAM to emerge as model of distance education for other public and private institutions in Latin America.
\end{abstract}

Distance education in Latin America, rather than being considered a second rate educational complement for traditional higher education, must be seen as a fundamental engine for restructuring other university systems, especially the public ones (Casas Armengol, 2002).

. . . the widespread use of new technologies in an organization does constitute a major cultural change. Furthermore, for such change to be successful, leadership of the highest quality is required (Bates, 2000).

Keywords: distance education; consolidation; project management; strategic planning

\section{Introduction}

At 450 years old, the National Autonomous University of Mexico (UNAM) is currently Mexico's most important public higher education and research institution. UNAM is the foundation upon which Mexico's public higher education system has been developed. UNAM is a public, decentralized, national, and autonomous institution that carries out teaching, research, and cultural activities throughout Mexico. Through its 23 colleges and schools, UNAM currently offers 71 Bachelor, 29 specialization, 35 Masters, and 33 Doctoral degree programs. More than half of all the research carried out in Mexico takes place at UNAM's 39 research institutes and centers. Over 6,000 continuing education activities are also offered each year to the benefit of more than 130,000 students (Agenda Estadística 2001). 
UNAM's Open University and Distance Education Coordination Center (CUAED) is responsible for strengthening continuing, open, and distance education across the University and throughout Mexico. CUAED aims to expand its continuing, open, and distance education programs both within and outside UNAM. For example, CUAED shares its open, distance and continuing education course programs and its "best practice guidelines" internally across UNAM's various schools and colleges. To serve broader societal needs throughout Mexico, CUAED also identifies educational and training needs of social, government, and business organizations.

To continue to reach its mandated objectives at a time of rapidly growing demand for continuing, open and distance education, CUAED found it needed to consolidate UNAM's diverse distance education activities. As such, CUAED developed the following three strategies, which were rolled out in lock-step over an 18 month period, starting in March 2002:

- Development of the Online University Program (Programa Universidad en Línea) and the PUEL System

- $\quad$ Creation of the Distance Education High Technology Center (CATED)

- A formal agreement was agreed upon that restructured the CUAED, and created UNAM's current Board of Distance Education

The objective of this article is to broadly outline the three strategies used by UNAM to consolidate its distance education activities. This paper examines the strategic activities that took place during the development and deployment phases, which lasted 18 months. It is felt that this case study may help other universities in developing countries define their own strategies in developing their own distance education programming.

\section{Strategy 1. Online University Program (Programa Universidad en LíNea) and the PUEL System}

The objective of the Online University Program (PUEL) is to help UNAM's many schools and colleges to develop their own online course materials for their numerous Bachelors, Masters and Doctorate programs, and for the over 6,000 continuing education courses offered each year by UNAM.

The use of new and emerging learning technologies, such as learning management systems (LMS), are necessary to meet the demands of increasing numbers of students studying to upgrade and enhance their knowledge and skills via distance education. However, the relatively slow adoption of Learning Management Systems - the cornerstone of many emerging distance education programs - often results, due to the high cost associated with purchasing and maintaining the software (Depow 2003). Because of the high costs associated with proprietary LMS and other technological platforms used for managing online courses (e.g., WebCT), CUAED developed its own "PUEL" system. In sum, PUEL is a home-grown platform used by UNAM to develop and administrate its online course offerings.

LMS are intended to address a range of pedagogical and technical issues such as learning and design theory, hardware and software purchases, student support services, student assessment, student interaction, instructional strategies, security and firewalls, and staffing. The goal of this type of platform is to provide an information system that can effectively handle students, teachers, course administration, and course materials in an online environment (Bidarra and Dias, 
2003). Many higher education institutions are currently using proprietary LMS products such as WebCT and BlackBoard. Nonetheless these proprietary solutions are often cost-prohibitive for many institutions, especially those in developing countries (Depow, 2003). In other words, many publically funded higher-education institutions - particularly those in developing countries cannot afford the development or acquisition of a proprietary LMS. An alternative solution, however, can be found in the wide and rapidly emerging range of non-proprietary, open source and free software LMS packages (Depow, 2003). PUEL's main objective, therefore, is to offer UNAM's Schools and Research Centers and other public institutions the resources they need to generate their own online courses and learning materials. Launched on June 16, 2003, PUEL is offered as an open source LMS through a free licensing agreement (see www.puel.unam.mx for details on this system). By November 30, 2003, over 560 licenses have been downloaded by institutions in 28 different countries (e.g., Japan, Mozambique, United States, and Canada, along with several countries throughout Latin American and Europe).

PUEL is divided into three modules: users' administration, course administration, and statistics. PUEL generates and stores activities in individual student binders, which allows students to refer to previously performed activities and receive continuous feedback from their tutors. Students can also edit and store their activities in their personal online binder. PUEL generates access reports for users which are available through webpage interfaces; it also generates statistics for each session in each course and manages different levels of security (i.e., administrator, editor, and user levels).

Figure I: PUEL website (wwwpuel.unammx)

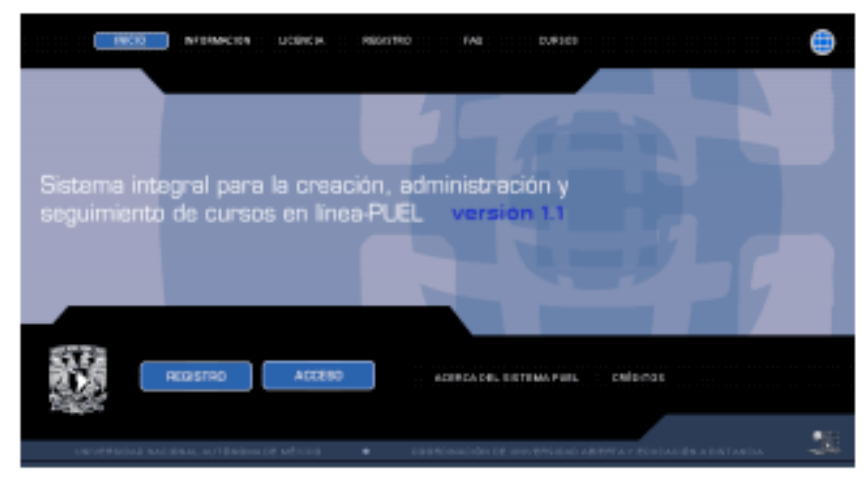

Institutions interested in starting an online program must factor in the costs of infrastructure (hardware), course contents, a technological platform or LMS, and appropriately trained staff (Uys, 2003). According to Uys: "Many aspects of the socio-economic and technological environment that are often taken for granted, must be explicitly addressed when introducing instructional technologies for open learning in developing settings. These include, among other things, participants' unfamiliarity with new instructional technologies, inadequate telecommunications infrastructure, unreliable power supply, competition for limited educational sector resources, and the need to provide basic educational facilities” (Uys, 2003).

After developing the PUEL System, the next step was to generate a scheme that would enable UNAM's numerous schools, colleges, and centers to develop their own online courses and course materials based on existing face-to-face course offerings. The basic idea here was not to reinvent the wheel, but instead to re-vamp the wheel so it could meet current and future educational demands. Because UNAM's various schools, colleges, and research centers have the necessary infrastructure and course contents, focused was therefore placed on developing and offering the 
PUEL LMS. To accomplish this task, a multi-disciplinary working group called "Núcleo PUEL" was assembled to bring the necessary expertise needed to coordinate and man the project (Berruecos, Gil, Morales and Bosco, 2003). Núcleo PUEL is comprised of a project integrator, a content expert, an instructional designer, a graphic designer, and a systems administrator. The project integrator is the "decision maker" who often coordinated several projects simultaneously. The content expert worked on specific projects, while the remaining experts worked on different projects, depending on the need for their particular expertise at various points in each project cycle/ lifespan.

In other words, the experts that comprised Núcleo PUEL effectively eliminated the need for "'everybody to know everything." For example, the content expert does not need to learn graphic design and programming required for developing online course material. This tactic was followed because it was proven at other institutions that multi-disciplinary groups are very effective. "each academic is working on some aspect of online conversion or course and program enhancement. Since academics have different ideas, backgrounds and levels of expertise, support staff (designers, editors, visual designers, etc.) are organized and trained to respond in a number of ways in each course team. This leads to interesting implications for human resource management. As the various learning platforms and their associated human resource needs evolve, there is a continual emergence of new position types, and levels within these types. Each learning system requires a unique blend of technical, design and pedagogical expertise, and once each position is established, the needs evolve rather quickly” (Davis, 2001). The PUEL group, therefore, ensures that only the most competent experts will develop high quality contents, thereby removing the task of course development from less skilled and typically less computer-literate staff. "While some teachers develop and use advanced Web-enhanced learning materials effortlessly, others struggle to acquire basic computer literacy skills. Where previously teaching staff were divided in their ability to use word-processors and spreadsheets, today's educators are divided by their ability to create and update their online course materials" (Depow, 2003). Over time, the course will be tutored by other colleagues, if necessary.

Figure 2. PUEL group ("Núcleo PUEL")

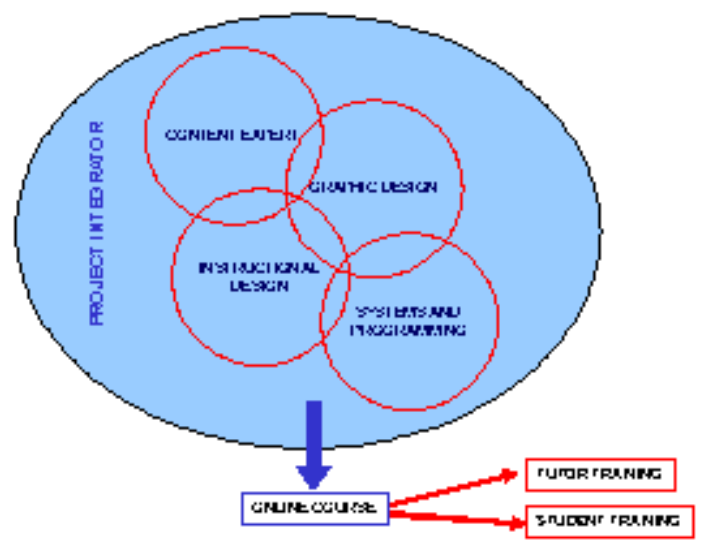

(Berruecos, Gil, Morales, and Bosco, 2003).

To consolidate the PUEL groups, a training strategy was identified and developed. To this end, CUAED now offers four online courses and "PUEL manuals" which guide users in installing, operating, administrating, planning, and designing online courses using the PUEL system. In October 2003, CUAED began delivering a free-of-cost, face-to-face, week long workshops to 
UNAM schools and research centers seeking to implement their own PUEL group. In order to participate in the PUEL workshop (which Schools and Research Centers use as a template for designing and installing their first course online) CUAED demands that each prospective PUEL group member meet certain baseline performance criteria. Adherence to this selection criteria, ensures that those charged with developing the online learning materials and courses will be able to do so after the end of the week long workshop. In other words, by the end of the workshop, each new PUEL group had combined theory and practice to develop (at minimum) the first topic of an online course, which they will continue working on at their own School or Research Center. CUAED also offers ongoing assistance to these groups if needed.

\section{Strategy 2. Distance Education High Technology Center}

In June 2002, the State of Tlaxcala offered UNAM a 9,000 square meter textile factory, built in 1884, for use as its Distance Education High Technology Center or in Spanish, Centro de Alta Tecnología de Educación a Distancia (CATED). CUAED stipulated that the CATED project include four academic areas, and defined an implementation strategy to be rolled out in five stages. The project included the rebuilding the factory, which entailed combining the original architectural elements of the old textile factory with modern installations and high technology:

- $\quad$ Distance Education High Technology Center (Stage 1 and 2)

- Convention Center (Stage 3)

- Multidisciplinary Research Projects (Stage 4)

- Cultural Center (Stage 5)

Figure 3. Stages of development of the Distance Education High Technology Center (CUAED)

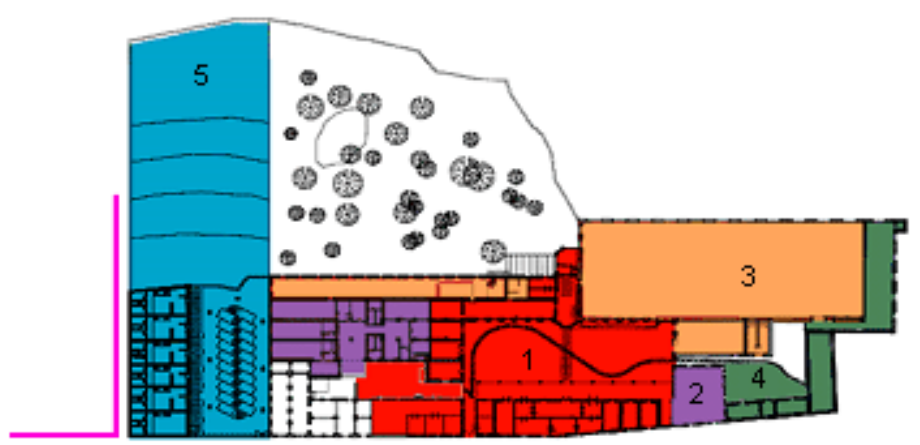

In March 2003, the Dean of the University (Rector) and the Governor of Tlaxcala signed a formal agreement, and by August 2003, the first stage of the CATED project was finished. CATED's first stage included building video-conferencing and computing rooms, training rooms, digital library, multimedia library, servers, central telecommunications infrastructure, Internet2, production labs, and a coffee shop. The second stage will include building television studios, preand post-production centers, and production labs. CATED's main objective is to develop the pool of human and technical resources necessary to design, develop, and implement distance education (online courses, television, video, video conferencing, multimedia). "Rather than overload the 
existing universities, this new institution would possess a technical, methodological, and administrative organization appropriate to distance teaching” (Garcia Aretio, 2001).

CATED's mission is to:

- Promote the use of information technology for distance education

- Promote and provide high technology services for the development of distance education to benefit academic institutions and UNAM students and alumni, as well as for other Mexican higher education institutions and international institutions (Berruecos and Berruecos, July 2002).

The objectives of CATED are to:

- Develop pedagogical, didactic, and technical models to offer "best practices" in the higher educational processes

- Provide training and support for research related to distance education and using technology for higher educational purposes

- Develop multidisciplinary projects

- Develop distance education courses with high technology: computing laboratories, television and video production studios, videoconferencing rooms, digital libraries, and development of websites

- Develop Internet and Internet2 didactic support materials for students and tutors

- Offer continuing courses for UNAM and other institutions' professionals, students, and graduates

- Publish research results on distance education and on the use of technology for higher educational purposes through different media

- Develop organized metadata, thesaurus, digital library systems, electronic publications, and websites

- Train the pool of human resources necessary in the use of new technologies for distance education

- Produce Internet, multimedia, television and video contents (Berruecos and Berruecos, March 2003)

CATED will offer courses on distance education development; provide consulting services on elearning; develop learning objects; and provide access to computing laboratories, videoconferencing rooms, television and video production studios, and digital libraries (Berruecos and Berruecos, April 2003). CATED’s Academic Project was divided into four areas:

- Academic, technical, and technological training for distance education development (i.e., learning-teaching processes, motivation, social learning, media and administration) 
- Content development for distance education (i.e., Bachelor degree programs, continuing education, and other academic projects such as learning objects and learning object repositories)

- Research on distance education (i.e., learning-teaching processes, use of media and technology, user motivation, distance education project administration, tutors training, best practices)

- Multidisciplinary projects (evaluated and approved by the University's Board of Distance Education). As an example, CUAED-CATED and the Anthropology Research Institute are currently developing the "University’s Pre-Hispanic Ceramic Virtual Museum” and the "Mexican Anthropology Site."

CATED and CUAED will also share responsibility for the development of other future academic projects, which will subsequently be evaluated by the Board of Distance Education.

\section{Strategy 3. Restructuring of the CUAED and the Creation of UNAM'S Board of Distance Education}

Now 30 years old, UNAM's Open University currently offers through its nine schools, 17 Bachelor degree programs, three specialization and one technical programs. Each school's Open University coordinator reports directly to the director of the school where the program is offered - e.g., six open Bachelor degree programs (Philosophy, History, Geography, English Literature, Education, Spanish and Latin-American Literature) of the School of Philosophy and Literature are coordinated by only one person.

Prior to September 2003, an Academic Board responsible for overseeing the operation of UNAM's Open University existed. The purpose of the old Academic Board was to approve each new Open University program before sending them to the University's Council (Consejo Universitario), the most important collegiate authority responsible for approving all academic programs at UNAM. However, CUAED typically only held one Academic Board meeting per year; and UNAM's Open University norms, rules and regulations had not been updated for over 30 years.

Figure 4. UNAM's Old Open University and Continuing Education Structure, prior to September

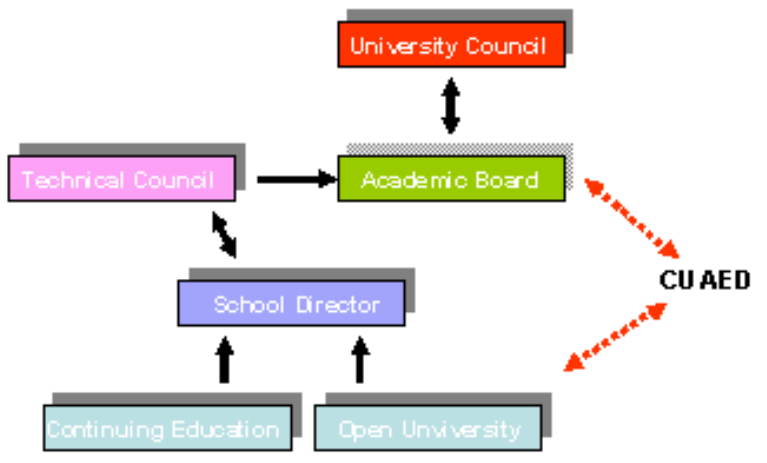


UNAM has 40 Continuing Education Centers, where programs are developed and coordinated by each school, often receiving previous approval of the school's collective authority (comprised of representatives from student, teacher and administrative officials). This collective authority is called the Technical Council (Consejo Técnico) of the School. As such, prior to 2003, no rules or regulations exist to guide the development and delivery of diploma programs, because each school was essentially free to decide what to offer and how to deliver it. Similarly, no viable norms, rules or regulations existed for distance education either. Indeed, a handful of schools throughout the University began developing and delivering distance programs within their own means, and these efforts were also largely piecemeal and unregulated.

In 2003, however, CUAED negotiated a proposal to restructure its functions and responsibilities. This proposal resulted in the creation of UNAM's current Board of Distance Education on September 19, 2003, when a formal agreement was signed by the Dean (Rector) of UNAM. The scope of this new Board of Distance Education is as follows:

- Open University and continuing education programs are the responsibility of each School and their Technical Councils

- The Board of Distance Education is responsible for evaluating and updating existing rules and regulations, and developing new distance education regulations, rules, and procedures with the overarching goal of guaranteeing academic and technical quality

- The Board of Distance Education is in charge of evaluating all distance education programs (Bachelors, diplomas, specializations, and graduate programs) developed by any academic institution of the UNAM

- CUAED will coordinate the Board of Distance Education

- CUAED is responsible for registering all UNAM distance and continuing education programs in UNAM's Distance and Continuing Education Catalogue

Figure 5. UNAM'S Distance Education after September 2003

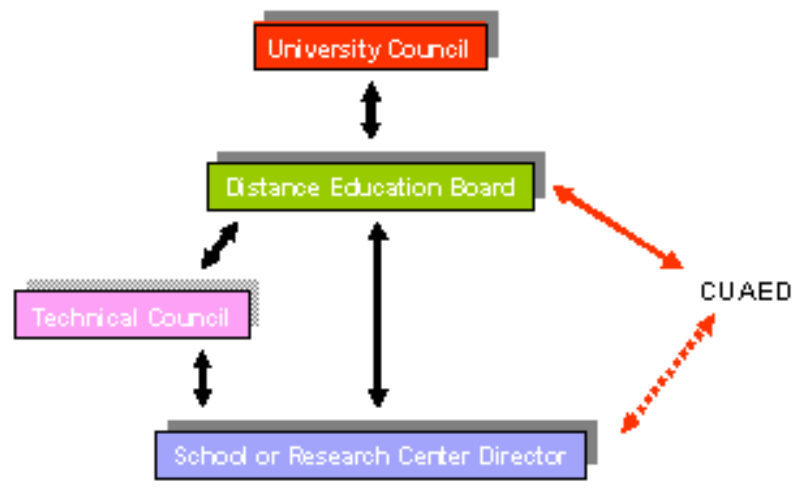

Like other University course offerings, the pedagogical restructuring required in distance education is deep and extensive. Some experts such as Collis (1996, p. xxii) feel that the "re- 
engineering" of distance education is most appropriate. As such, it could be said that a new era of distance education is now visible on the horizon, one in which distance education will develop into an extraordinarily open, flexible, and variable form of teaching and learning that can be adapted and adjusted to meet the learning requirements of students based on demographic variables such as age, social background, vocational orientation, etc. As such, a clear studentoriented form of studies must be created (Peter, 2000).

\section{Conclusion}

Tremendous inroads and advancements have been made regarding distance education offered by UNAM over the past 18 months. Via the three strategies mentioned above, the University now provides an exemplar for other public universities to follow. Moreover, within these three strategies, three important key premises were followed during the process.

\section{1. "Do First"}

Many institutions begin the transition to distance education by first trying to establish norms, rules, and regulations as the springboard upon which to start developing their programs. At UNAM, the strategy used was completely opposite: CUAED first began developing its distance education programs and establishing its Distance Education High Technology Center, and these projects in turn generated "internal pressure" which drove the negotiation processes with the University authorities, and ultimately resulted in the creation of the current Board of Distance Education whose mandate is to provide quality guidelines on various educational offerings. This new Board of Distance Education is now responsible for developing all regulatory norms, rules, and regulations for the University's distance education offerings.

\section{Stages}

The Distance Education High Technology Center project was rolled out in stages. This tactic divided the total cost of the project into five phases. As a result, it was much easier to convince financial authorities to invest in a project that was defined step-by-step, than requesting a total lump-sum investment at the outset.

\section{Delegation}

CUAED is no longer responsible for developing all UNAM's distance education programs. Given the enormous scope and reach of UNAM's 71 Bachelor degree programs and 6,000 plus continuing education programs, it simply would have been impossible for CUAED to develop numerous programs in an efficient and cost effective manner. With the development of the PUEL system, however, CUAED now provides the necessary resources (after basic training is complete), which it then delegates to each School and Research Center. CUAED also coordinates the validation and registration of each distance learning program through the Board of Distance Education; it does not administer these programs, as that is the responsibility of each school. In sum, CUAED is responsible for training individual schools' PUEL groups on how to develop their own online programs. Through its Distance Education High Technology Center, CUAED trains technical and academic personnel the "how to" and "best practices" of developing distance education courses, and then when the courses are ready to be reviewed and approved by the Board of Distance Education, CUAED handles that process too. In simple terms, CUAED enables distance education - it does not dictate it. 
Keegan (1996) stated that "governments in both developed and developing countries no longer have the money to build and maintain buildings for 100,000 students a year." In today's world, distance education has emerged to become viable option for many nations and "the growing strategic importance of higher education, coupled with the need to reorganize and radically transform Latin America's university system, is essential to help Latin America catch up to other countries around the world" (Casas Armengol, 2002). Within the context of a globalizing world economy, CUAED will enable Latin-American countries to develop their own capacity for developing distance education programming (.e.g., Spanish contents will be available for Latin America's Spanish speaking population) to meet the growing educational needs of their people. This reinforces the statement by Bates (2001) who said: "help must be provided in a way that reduces rather than increases dependency, by enabling local institutions to develop their own capacity for online teaching adapted to the needs of their own society.”

The National Autonomous University of Mexico is now a reference model which other institutions can use as a template or exemplar as they transition to distance education, especially for other Latin-American educational institutions. Through CUAED's strategies and results, it has been proven that even when resources are scarce, there are strategies that can help higher education institutions enter into the world of distance education in a cost effective and efficient manner.

\section{References}

Agenda Estadística (2001). Universidad Nacional Autónoma de México. Dirección General de Estadística y Desarrollo Institucional. Retrieved December 23, 2003 from: www.estadistica.unam.mx

Bates. A. W. (2001). International Distance Education: Cultural and ethical issues. Distance Education, 22(1) 122 - 136.

Bates, A. W. (2000). Managing Technological Change. Strategies for college and university leaders. San Francisco: Jossey-Bass.

Berruecos Carranza, C., Rivera, M. C. G., Morales Vega, L., and Bosco Hernández, M. D. (2003). Integración de Proyectos y Diseño Instruccional en los Programas Educativos en Línea. CUAED-UNAM.

Berruecos Carranza, C., Morales Vega, L., and Quiroz Schumman G. (2003, September). Desarrollo de Programas Interinstitucionales de Educación en Línea. Manual de Operación. CUAED-UNAM.

Berruecos Villalobos, J. M., and Berruecos, C. (2002, April). Centro de Alta Tecnología para la Educación Abierta, Continua y a Distancia, UNAM.

Berruecos Villalobos, J. M., and Berruecos, C. (2002, June). Centro de Alta Tecnología para la Educación a Distancia, UNAM.

Berruecos Villalobos, J. M., and Berruecos, C. (2002, July). Proyecto Tlaxcala-UNAM” Coordinación de Universidad Abierta y Educación a Distancia, UNAM. 
Berruecos Villalobos, J. M., and Berruecos, C. (2003, February). Centro Regional de Formación para la utilización pedagógica de las NTIC y de la EAD en la educación superior OUICOLAM (Convocatoria). Coordinación de Universidad Abierta y Educación a Distancia, UNAM.

Berruecos Villalobos, J. M., and Berruecos, C. (2003, March). Proyecto Académico TlaxcalaUNAM. Coordinación de Universidad Abierta y Educación a Distancia, UNAM.

Berruecos Villalobos, J. M., and Berruecos, C. (2003, April). Centro Regional de Formación para la utilización pedagógica de las NTIC y de la EAD en la educación superior OUICOLAM (Aportación UNAM). Coordinación de Universidad Abierta y Educación a Distancia, UNAM.

Bidarra, J., and Dias, A. From Cognitive Landscapes to Digital Hyperscapes. International Review of Research in Open and Distance Learning, 4(2). Retrieved December 23, 2003 from: http://www.irrodl.org/content/v4.2/bidarra-dias.html

Casas Armengol, M. (2002). Global and Critical Visions of Distance Universities and Programs in Latin America. International Review of Research in Open and Distance Learning, 3(2). Retrieved December 23, 2003 from: http://www.irrodl.org/content/v3.2/armengol.html

CATED (2003, August). Centro de Alta Tecnología de Educación a Distancia. UNAM

Davis, A. (2001). Athabasca University: Conversion from traditional distance education to online courses, programs and services. International Review of Research in Open and Distance Learning, 1(2). Retrieved December 23, 2003 from: http://www.irrodl.org/content/v1.2/au.html

Depow, J. (2003). Open Source Software: Two learning management systems. International Review of Research in Open and Distance Learning, 4(2). Retrieved July 20, 2004 from: http://www.irrodl.org/content/v4.2/technote_xxv.html

Garcia Aretio, L. (2001) The Technological Consolidation of UNED of Spain in IRRODL. International Review of Research in Open and Distance Learning, 2(1). Retrieved December 23, 2003 from: http://www.irrodl.org/content/v2.1/aretio.html

Keegan, D. (1996). Foundations of Distance Education. Third Edition. London: Routledge.

Newman, W. L. (1997) Social Research Methods: Qualitative and quantitative approaches. Fifth Edition. Toronto: Allyn \& Bacon

Peters, O. (2000). Digital Learning Environments: New possibilities and opportunities. International Review of Research in Open and Distance Learning, 1(1) retrieved December 23, 2003 from: http://www.irrodl.org/content/v1.1/otto.html

Uys, P. M. (2003). Critical Success Factors in the Infusion of Instructional Technologies for Open Learning in Development Settings: The case of the University of Botswana. International 
Review of Research in Open and Distance Learning, 4(2). Retrieved December 23, 2003 from: http://www.irrodl.org/content/v4.2/uys.html

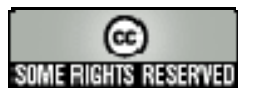

